DOI: $10.6060 / \mathrm{mhc} 181220 \mathrm{t}$

\title{
Emerging Perspectives on Applications of Porphyrinoids for Photodynamic Therapy and Photoinactivation of Microorganisms
}

\author{
Veronica Almeida-Marrero, José Antonio González-Delgado, and Tomás Torres ${ }^{@}$ \\ Department of Organic Chemistry, Universidad Autónoma de Madrid, 28049 Madrid, Spain \\ ${ }^{\circledR}$ Corresponding authorE-mail: tomas.torres@uam.es
}

\begin{abstract}
The use of photosensitizers (PSS) in photodynamic therapy (PDT) and photodynamic inactivation of microorganisms (PDI), as well in other biomedical techniques as medical imaging, represents a challenge for improving given properties that are desired in a biological media, such as water solubility, lack of aggregation and biocompatibility, among others. This review shows the most recent and important examples of the conjugation of photosensitizers to different biomolecules to achieve this goal. The manuscript is written in an accessible way in order to give a general vision of the recent advances stimulating at the same time the curiosity of the reader.
\end{abstract}

Keywords: Porphyrins, phthalocyanines, photosensitizers, photodynamic therapy, photoinactivation of microorganisms, medical imaging.

\section{Новые перспективы применения порфириноидов Аля фотодинамической терапии и фотоинактивации микроорганизмов}

\author{
В. Алмеила-Марреро, Аж. А. Гонсалес-Аельгадо, Т. Торрес ${ }^{@}$ \\ Кафедра органической химии, Мадридский автономный университет, 28049 Мадрид, Испания \\ ${ }^{\circledR}$ E-mail: tomas.torres@uam.es
}

\begin{abstract}
Использование фотосенсибилизаторов (PSS) в фотодинамической терапии (PDT) и фотодинамической инактивации микроорганизмов (PDI), а также для медицинской визуализации, налагает определенные требования на их свойства - растворимость в воде, отсутствие агрегации, биосовместимость и др. В обзоре приведень актуальные примеры конъюгаџии PSs со сложными биомолекулами, направленной на усиление желаемых свойств фотосенсибилизаторов в биологических средах.
\end{abstract}

Ключевые слова: Порфирины, фталоцианины, фотосенсибилизаторы, фотодинамическая терапия, фотоинактивация микроорганизмов, медицинская визуализация.

\section{Introduction}

Photodynamic therapy (PDT) and photodynamic inactivation of microorganisms (PDI) are two approaches related to photochemistry where the generation of singlet oxygen $\left({ }^{1} \mathrm{O}_{2}\right)$, a reactive oxygen specie (ROS) produced by the excitation of a photosensitizer (PS) in a certain wavelength of light, is used to kill cancer cells, in the case of PDT, or microorganisms as bacteria, viruses and fungi, in the case of PDI. Otherwise, medical imaging is a promising biomedi- cal technique where using a contrast agent, realistic images of biological structures could be obtained. ${ }^{[1-4]}$

The use of PSs in this field has been explored along many years. Apart from the generation of ${ }^{1} \mathrm{O}_{2}$, the fluorescence produced by the PS could be used for imaging purposes. The most important PSs that have been employed for biomedical applications are phthalocyanines (Pcs), porphyrins (Pors) as well as BODIPYs, chlorins and corroles, among others, comprising the so called second-generation of PSs. ${ }^{[5]}$ They circumvent the disadvantages presented 
by first-generation (porfimer sodium (Photofrin $®$ ) and others), like the prolonged patient photosensitivity and a very low absorption of long wavelengths of light. ${ }^{[6]}$ The major problems presented by this second generation are the aggregation, low solubility and the lack of specificity in biological media. However, this is addressed by third-generation of PSs, in which they are conjugated to biomolecules that decrease the aggregation, increase solubility, and give biological specificity.

Second-generation PSs can be conjugated to diverse biomolecules in order to enhance the desired properties mentioned before. Among them are peptides, proteins, antibodies, protein cages, carbohydrates, nucleic acids, liposomes, hormones and folic acid, with all of them contributing in a different way with different properties after bioconjugation. In the case of peptides and protein structures, they can enhance the solubility of the PS, but the most important characteristic is that they give biological specificity, vehiculizing the PS to different biological targets. ${ }^{[7]}$ Folic acid, a water-soluble vitamin that is important for DNA synthesis, acts as biological target too, and with the bioconjugation with nucleic acids, the PS could be incorporated into the genetic material and can act as a modulator. ${ }^{[8]}$ Liposomes can act as nanocarriers, because they have a hydrophobic inner cavity that could allow the inclusion of the PS inside this cavity, apart from the incorporation into the hydrophobic environment of the membrane, ${ }^{[9]}$ and finally, carbohydrates can enhance the solubility of the PSs and act as nanocarriers too. ${ }^{[10]}$ Furthermore, aggregation phenomena could be avoided by conjugation to these biomolecules. The bioconjugation strategies have been reviewed recently ${ }^{[1]}$ and will not be treated here because they fall out of the scope of this review. The purpose of this review, divided in different sections depending on the type of PS (Pcs, Pors and other porphyrinoids) is to explore, using recent and important examples, the advantages of the bioconjugation of PSs to different biological molecules, encouraging the interest of the reader in these emerging fields.

\section{Phthalocyanines}

The advantages that presents the bioconjugation of Pcs to peptides, proteins and antibodies make that had been extensively described in the literature (Figure 1). ${ }^{[7,12]}$ Thus, the strategy of bioconjugating PSs to peptides has been widely used in the last years due to the improvement of properties in the biohybrids such as the solubility in aqueous media and biocompatibility, among others. Furthermore, the possibility of using different kinds of peptides (natural and/or synthetic) increases the affinity and selectivity towards biological targets.

In this way, PSs have been linked to amino acids, enhancing their water solubility and biocompatibility among other properties. ${ }^{[13-15]}$ On the next level of complexity, peptides that target the epidermal growth factor receptors (EGFR), ${ }^{[16]}$ gastrin-releasing peptide (GRP) and integrin receptors, ${ }^{[17]}$ and antimicrobial peptides,${ }^{[18]}$ have been the most used in the bioconjugation to PSs.

In one of the most representative examples, Vicente and co-workers used two peptides with sequences LARLLT
(EGFR-L1) and YHWYGYTPQNVI (EGFR-L2) linked to $\mathrm{Zn}(\mathrm{II}) \mathrm{Pc}$ demonstrating a low immunogenicity, moderate ability of conjugation and excellent EGFR targeting capacity. ${ }^{[19]}$ These biohybrids were studied in human carcinoma cell lines A341 and Hep2, and in the human colorectal cell line HT-29 where the best results were obtained by $\mathrm{Zn}$ (II) Pc-EGFR-L1 conjugates. This biohybrid exhibits a good ability of targeting and internalization, and a low dark toxicity that may be caused by cationic charges present in its structure in comparison to the neutral Zn(II)Pc-EGFR-L2 conjugate. Very recently, $\mathrm{Yu}$ et al. developed a $\mathrm{Zn}$ (II) Pc-GE11 biohybrid for photodynamic therapy and bioimaging with promising results. ${ }^{[20]}$ This biohybrid showed a high cellular uptake on carcinoma cell line A431 and an excellent accumulation in tumour-bearing mice. Furthermore, this bioconjugated was cytotoxic upon irradiation but non-toxic in dark.

Photoimmunotherapy (PIT) ${ }^{[21]}$ consists in the development of bioconjugates composed by the binding of antibodies and PSs. Monoclonal antibodies (MAbs) make the function of molecular recognition, and PSs contribute with the phototoxic effect. The maintenance of the properties of both is the major challenge in the synthesis of these types of biohybrids.

Kobayashi and co-workers have synthesized $\mathrm{Si}(\mathrm{IV})$ Pc-MAb conjugates with a $\mathrm{Si}(\mathrm{IV}) \mathrm{Pc}$ as a PS, denominated IR700. [22] Two MAbs were used to target EGFR; one directed to EGFR1 (HER1), panitumumab, and the other one to EGFR2 (HER2), trastuzumab. ${ }^{[23]}$ The conjugates showed an interesting PDT activity when there were interactions between the bioconjugates and cell membranes. The activation of the PS at high wavelengths, was the reason why this technique was called NIR-PIT, ${ }^{[24]}$ and the emission of fluorescence for imaging techniques and the capacity of non-aggregation resulted to be important advantages in the use of these PSs in PDT. The design and synthesis of these biohybrids discovered a new research field with the exploitation of the properties showed.

On the other hand, GRP and $\alpha_{\mathrm{v}} \beta_{3}$ integrin are proteins that are expressed in different tumours, being a receptor of a peptide called bombesin in the first case, and of a peptide called RGD triad or arginylglycylaspartic acid in the second case. ${ }^{[17,25]}$ Van Lier et al. have developed different $\mathrm{Zn}(\mathrm{II})$ Pc-bombesin and Zn(II)Pc-RGD conjugates. ${ }^{[26]}$ These bioconjugates were evaluated in cell lines that express GRP and integrin receptors and the results showed that the first one, a $\mathrm{Zn}(\mathrm{II}) \mathrm{Pc}$-bombes in biohybrid, expressed a good aqueous solubility and was a potential candidate for being used as fluorescence imaging probe and photodynamic agent.

The fact that the conjugation of PSs and serum proteins, as albumin and low density lipoproteins, causes an improvement of endocytosis and phototoxicity, makes these proteins interesting nanocarriers for these type of drugs. ${ }^{[12]}$ Human serum albumin (HSA), considered the most abundant protein in the human plasma, intervenes in many biological processes, as cancer. ${ }^{[27]}$ Van Lier and co-workers have published two studies of non-covalent ${ }^{[28]}$ and covalent ${ }^{[29]}$ Pc-BSA (bovine serum albumin) biohybrids, but unfortunately, the photodynamic activity of them was low, maybe due to an aggregation in the BSA pocket. Related to that, it has been reported in the literature that the interaction of PS 
a)

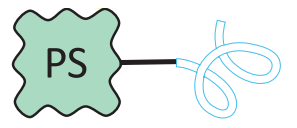

b)

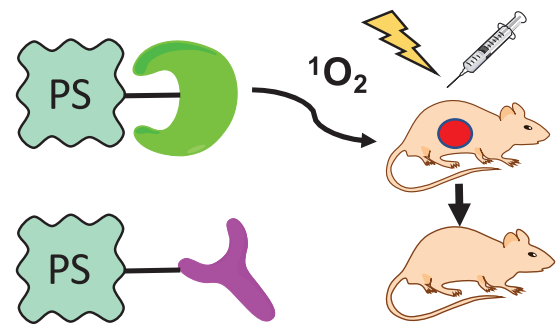

Figure 1. Bioconjugation of PSs to a) peptides, b) proteins, and c) antibodies allow the enhancement of water solubility, reduce aggregation and give biological specificity. The application of these bioconjugates could treat tumour processes under the irradiation of light with the generation of ${ }^{1} \mathrm{O}_{2}$.

and serum proteins can produce the quenching of singlet excited states, and in consequence, the decrease of the production of ${ }^{1} \mathrm{O}_{2} \cdot{ }^{[30,31]}$ In other way, a commercially $\mathrm{Si}(\mathrm{IV}) \mathrm{Pc}$ (IR7000DX) has been linked to HSA and RGD peptides, and the production of ${ }^{1} \mathrm{O}_{2}$ was measured in ovarian cancer cells. ${ }^{[32]}$ These bioconjugates demonstrated to be non-toxic to normal cells, and showed good results in cellular penetration and phototoxicity.

Apart from these examples, many others are described in the literature for tumour targeting. However, the field is very extensive, and will not be treated in this review.

Related to the conjugation of proteins and PSs, the use of protein cages, as virus-like-particles (VLPs) and ferritin has been explored extensively for the opportunities offered by them, as the introduction of different nanomaterials into their inner cavity, and the functionalization of the outside of the protein cage, for acting as nanocarriers. ${ }^{[33,34]}$

$\mathrm{Zn}(\mathrm{II}) \mathrm{Pc}$ and $\mathrm{Ru}(\mathrm{II}) \mathrm{Pc}$ have been encapsulated in the inner cavity of Cowpea Chlorotic Mottle Virus (CCMV), ${ }^{[35,36]}$ in order to study the reassembly of the viral capsid, that could act as template in the self-organization of these proteic structures. These systems are very interesting in the design of nanocarriers for the transport of hydrophobic PSs in the biological media, with the maintenance of the photophysical and photochemical properties of the PS inside the inner cavity (Figure 2). In the case of ferritin, photoactive protein crystals composed by an octacationic $\mathrm{Zn}(\mathrm{II}) \mathrm{Pc}$, a pyrene moiety and ferritin have been described, for the different purposes as PDI among others. ${ }^{[37]}$

As well as proteins, nucleic acids (DNA and RNA) or their components can be associated with PSs in order to address specific biological targets or modulate their properties in biological media including fluorescence probes and fluorescence quenchers. In 2009, Shangguan and co-workers reported an example of linkage between a nucleobase and a Pc. ${ }^{[38]}$ They developed a $\mathrm{Zn}$ (II)Pcthymine conjugate as a highly selective and reversible $\mathrm{Hg}^{+2}$ sensor. Regarding to fluorescent probes, in 2009 Soper et al. prepared two different $\mathrm{Zn}$ (II)Pc linked to several oligonucleotides using a double-labelled dimerizationbased molecular beacon (DBMB) with NIR-emission. ${ }^{[39]}$

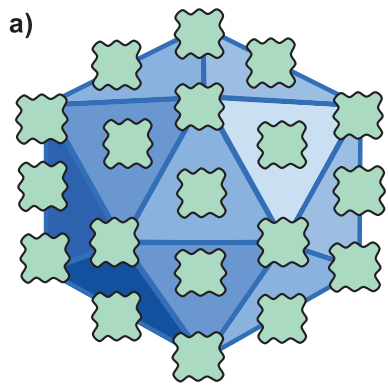

b)

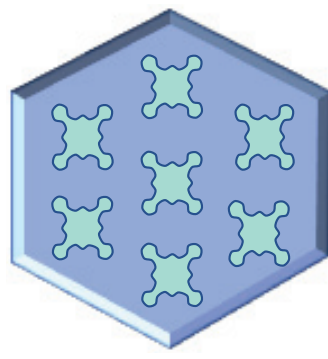

Figure 2. Schematic representation of a) the cover of VLPs with PSs, and b) the incorporation of PSs in the inner cavity of VLPs. One of the major advantages is the use of these protein structures as nanocarriers that can contribute enhancing solubility and specificity, among other properties.

These systems produced good quenching efficiencies (low light scattering and autofluorescence), a double extinction coefficient and fluorescent photon yield being promising candidates for live cell imaging. More recently, in the same group, a $\mathrm{Zn}$ (II)Pc conjugated to oligonucleotides, specifically L1-EN (Long Interspersed Element 1 endonucleases), that is implicated in genome instability and other diseases, has been used as a NIR fluorescence quenching system to monitor changes in enzymatic activity. ${ }^{[40]}$ Specifically, a controlled $\mathrm{H}$-aggregation of one $\mathrm{Pc}$ is the fluorescence on/ off mechanism implicated in this system. In 2010, Zimcik et al. developed different azaphthalocyanines (AzaPcs) linked to several oligonucleotides as new dark quenchers. ${ }^{[41]}$ These conjugates were synthetized in solid-phase and compared to well-established dark quenchers showing better results in some cases. Very recently, the same group linked oligonucleotides to an unsymmetrical $\mathrm{Zn}$ (II)AzaPc at the 3'-end and a fluorophore at the 5'-end for being used as dark quencher too. ${ }^{[42]}$ This bioconjugate showed a large absorption spectrum and excellent quenching efficiencies compared to well-established dark quenchers.

In other way, liposomes are spherical vehicles composed by two lipid layers and that present an inner cavity, that can allow the incorporation of PSs both inside the cavity and inserted into the membrane. For this reason, liposomes are excellent vehicles in order to transport all type of PSs. ${ }^{[43]}$ Another advantage of these systems is the non-aggregation of the PSs, so that properties keep intact such as ${ }^{1} \mathrm{O}_{2}$ generation and fluorescence in in vitro and in vivo studies. [44] Furthermore, more complex liposomes conjugates or ternary biohybrids have been also reported in literature during the last years, for example, liposome-PS conjugates incorporating antibodies, peptides or proteins on the outer layer in order to address more selectively to the target (Figure 3). The applications of liposome-PS biohybrids have been widely varied and studied, for instance, for imaging techniques, ${ }^{[45]} \mathrm{PDI}^{[46-49]}$ and PDT. ${ }^{[50-56]}$

Regarding to ternary conjugates, Huehns and co-workers encapsulated a water-soluble Pc, sulphonated aluminium phthalocyanine (Al(III)Pc), into liposomes which had a targeting monoclonal antibody $791 \mathrm{~T} / 36$ on the outer surface. ${ }^{[57]}$ This biohybrid was tested in two cell lines bearing a specific antigen (791T, an osteosarcoma and C170, a colorectal car- 


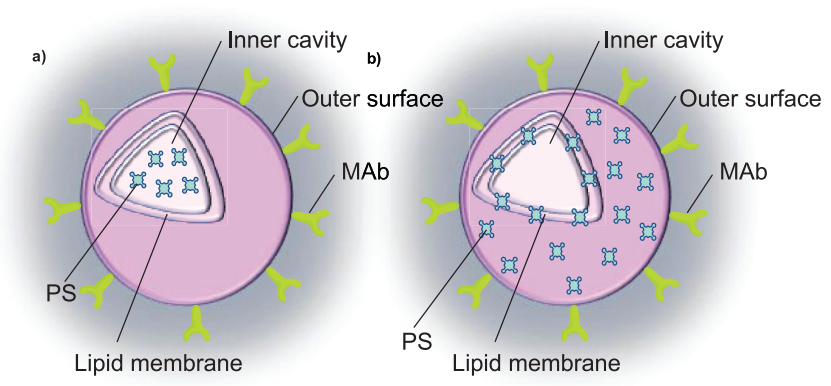

Figure 3. Schematic representation of ternary complexes constituted by liposomes, MAbs and PSs. a) shows the incorporation of PSs into the inner cavity of the liposomes and the decoration of the outer face with MAbs that can give biological specificity. b) shows the incorporation of PSs into the membrane next to the incorporation of the mentioned MAbs.

cinoma) demonstrating, unlike free Pc, a scarce dark toxicity and a high phototoxicity of the system in both cases. Three years later, this group coupled the same Pc and liposome to polyclonal sheep anti-mouse-Ig antibody and anti-CD3 antibody ${ }^{[58]}$ In both cases, excellent results were obtained with a high selectivity towards malignant cells. Another more recent example was reported by Heger and co-workers using $\mathrm{Zn}(\mathrm{II}) \mathrm{Pc}$ and liposomes. ${ }^{[51]}$ Previously, this system was tested in tumour cells showing a moderate phototoxicity but a limited cellular uptake. In order to overcome this drawback, the previous conjugated was coated by a singledomain antibody (sdAb) against human EGFR showing a more selective cell uptake and increasing PDT efficacy. ${ }^{[59]}$

On the other hand, sulphonated Al(III)Pc-liposomes were covered by transferrin, an overexpressed receptor found in tumour cells, for instance, HeLa cells. ${ }^{[60]}$ The obtained results showed that this ternary biohybrid was ten times more photocytotoxic than free $\mathrm{Al}$ (III)Pc (being untargeted Al(III)Pc-liposome not photocytotoxic) due to its higher cell uptake. This group also used the same system in 2004, but now on superficial bladder tumours presenting a cell death of more than 3 logs. ${ }^{[61]}$ Another interesting approach was developed by Mao and co-workers in 2009 when they used a Zn(II)Pc-liposome assembled on the engineered M13 phage, a rod-like virus that only infects bacteria and not humans. ${ }^{[62]}$ This complex increased the $\mathrm{Zn}$ (II)Pc fluorescence in the lipid bilayer and could be incorporated in breast-cancer cells.

As an interesting example, hollow Pc-nanospheres have been synthesized through thiol-ene 'click' chemistry by Hota et al. ${ }^{[63]}$ The authors suggested that these systems can allow the incorporation of different drugs by the inclusion in the inner cavity, or specific ligands by the linking to Pcs by a covalent way or through the coordination to the central metal atom, to direct these systems to specific tissues. The system showed excellent photodynamic properties and could be used for different purposes as medical imaging.

By other way, cholesterol, a biomolecule with a high importance in the constitution of cell membranes, has a crucial role in cell growth, ${ }^{[64]}$ being implicated in the production of cancer cells. Segalla et al. have tested the photodynamic activity in mice carrying a MS-2 fibrosarcoma of Ge(IV) Pc-cholesterol conjugates obtaining good results of phototoxicity, after their inclusion into liposomes. ${ }^{[65]}$

The synthesis of bioconjugates of Pcs, estradiol and estrone that are hormones that are overexpressed in breast cancer cells, ${ }^{[66]}$ has been carried out too. Van Lier et $a l$. have synthesized different biohybrids of $\mathrm{Zn}$ (II)Pc-estradiol with a different configuration and explored the different responses of photodynamic activity. ${ }^{[67]}$ With the introduction of different spacers into the structure of the bioconjugates, they did not observe any change in the phototoxic effect.

Significantly, carbohydrates are good candidates to be conjugated to PSs for PDT and PDI. They are biomolecules that intervene in processes of cellular recognition and offer good properties as a high aqueous solubility, being good candidates for tumour targeting. ${ }^{[68,69]}$ This review will be focused in the description of some examples of bioconjugation between different PSs and cyclodextrins and polysaccharides as cellulose, dextran and chitosan.

Cyclodextrins $(\mathrm{CD})^{[70]}$ are interesting nanocarriers that can encapsulate different drugs into the inner cavity of their structure, giving good solubility in aqueous media. Two strategies are useful in the generation of complexes between PSs and CD, being the formation of covalent bonds and the encapsulation into their inner cavity. The synthesis of $\beta-C D$ and 4-nitrophthalonitriles derivatives has allowed the cyclotetramerization of them for the formation of $\mathrm{Zn}$ (II)Pc complexes. ${ }^{[71]}$ In other way, Tomé and co-workers have explored the linkage of $\alpha-C D, \beta-C D$ and $\gamma-C D$ to a $\mathrm{Zn}(\mathrm{II}) \mathrm{Pc}$, and the effect on the PDT activity of the CD macrocycle size in UM-UC-3 human bladder cancer cells..$^{[72]}$

Cellulose is another carbohydrate that has been used for the synthesis of carbohydrate-PS bioconjugates. Rodshaped cellulose nanocrystals (CNC) express interesting properties and are considered excellent nanomaterials. [73] The conjugation between these nanomaterials and PSs has been explored in the literature, for example, through the immobilization of $\mathrm{Zn}$ (II)Pc onto the CNC surface with the generation of ${ }^{1} \mathrm{O}_{2}$, carried out by Anaya-Plaza et al., ${ }^{[7]}$ for the study of PDI effect in C. albicans, S. aureus and E. coli (Figure 4).

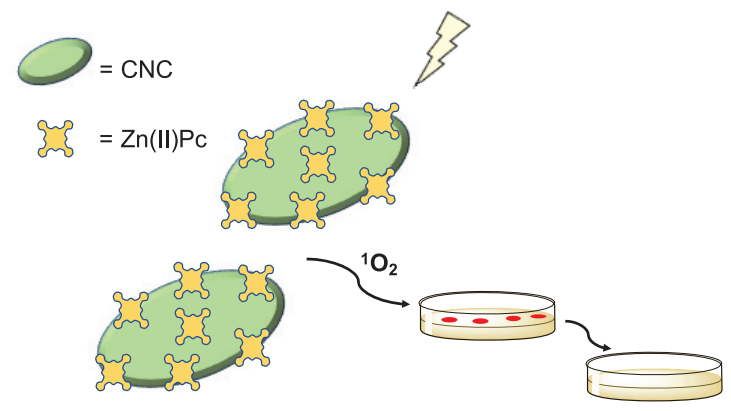

Figure 4. Upon illumination, $\mathrm{Zn}(\mathrm{II}) \mathrm{Pc}$ can kill microorganisms as C. albicans, $S$. aureus and E. coli.

In other way, dextran is a different biopolymer that shows exceptional properties for its use as a nanomaterial and that has been linked to PSs. ${ }^{[75]}$ Sortino and co-workers have published the synthesis of supramolecular hydrogels 
composed by $\mathrm{Zn}$ (II)Pc, dextran, $\beta-\mathrm{CN}$ and a photodonor as possible agents in PDT and PDI. ${ }^{[76]}$

Finally, the use of dendrimers that can act as nanocarriers has been described in the literature too. These nanosystems may be used for endovascular-PDT or imaging, endovascular real-time and follow-up therapy monitoring and endovascular theranostics, in particular, in atherosclerotic cardiovascular diseases. Furthermore, polymeric micelle-phthalocyanine nanosystems can be useful for the same purposes (Figure 5). In these systems, one or more Pcs can be payloaded. ${ }^{[77,78]}$

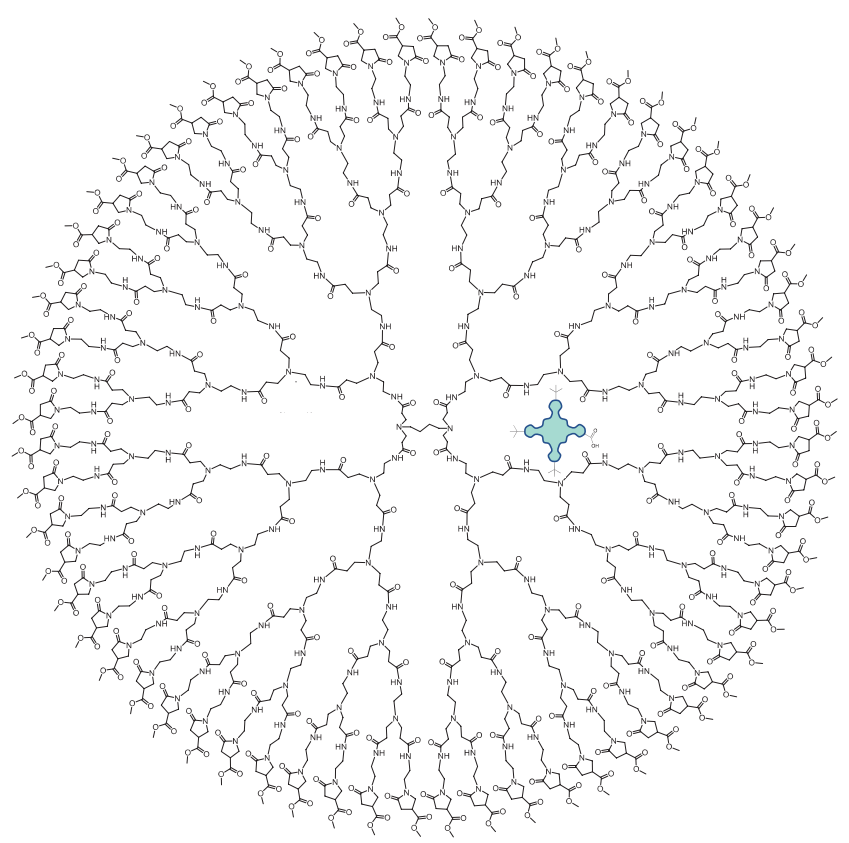

Figure 5. Scheme of a Zn(II)Pc (TT1) payloaded into a dendrimer, that acts as a nanocarrier for PDT and imaging of atherosclerotic cardiovascular diseases.

\section{Porphyrins}

The conjugation of Pors and peptides has been focused on nuclear targeting, antimicrobial peptides and biohybrids with multiple sequences of peptides. In 2005, Kahl and coworkers linked a NLS to $\mathrm{H}_{2}$ Por $^{\left[{ }^{[79]}\right.}$ In in vitro studies, this biohybrid was able to associate non-covalently with low density lipoproteins (LDL) thus allowing the entry of the PS into cancer cells overexpressing LDL receptors. In 2008, Vicente and co-workers used the same $\mathrm{H}_{2}$ Por linked to NLS peptides and cell penetrating peptides (CPP) demonstrating an excellent accumulation within human HEp2 cells. ${ }^{[80]}$ Two conjugates were the most cytotoxic and stable under nonenzymatic conditions but not in proteases, showing different cellular localization. The same year, another $\mathrm{H}_{2}$ Por-CPP conjugate, $\mathrm{H}_{2}$ Por-HIV-1 Tat (48-60) previously synthetized by the same group, showed low dark cytotoxicity, high phototoxicity and in vitro cellular uptake and in vivo biodistribution by using PC-3M human prostate cells. ${ }^{\left[{ }^{81,82]}\right.}$ Finally, another approach about Por-peptide conjugates is the use of antimicrobial peptides for PDI. In this sense, tricationic TriMPyPor (tri- $N$-methylpyridiniumyl)porphyrin was linked to apidaecin, an antimicrobial proline-rich peptide, promoting the binding of the PS-apidaecin conjugate to the bacterial outer membrane. ${ }^{[83]}$ The phototoxic studies showed that this conjugate is an effective photosensitizing agent against Gram-negative bacteria but without increasing the generation of ${ }^{1} \mathrm{O}_{2}$ for bearing apidaecin moiety.

Furthermore, proteins have been conjugated to Pors too. Lipoproteins are natural particles that are the responsible of the transport of different compounds through the organism. LDL have been used for the design and synthesis of different biohybrids. Interestingly, the LDL receptor appears in an overexpressed way in cancer cells, so by this manner LDL could be promising nanocarriers for different types of PSs. ${ }^{[84,85]}$ Among the strategies of bioconjugation to LDL, the most important are the formation of covalent and non-covalent interactions, and the use of the protein core of LDL for the introduction of the PS. In order to keep intact the LDL properties, the non-covalent interaction on the surface is the most successful way to synthesize these types of biohybrids. ${ }^{[86]}$ An interesting example carried out by Tang et al. is the synthesis and characterization of fluorinated $\mathrm{H}_{2}$ Por and $\mathrm{Zn}(\mathrm{II})$ Por derivatives that have been conjugated to glucose units for an improvement of the conjugation to LDL using non-covalent interactions. ${ }^{[87]}$ The authors observed that the $\beta$-lactonization of the macrocycle improved the production of ROS against HeLa cells.

In the same line as Kobayashi, Maruani et al. have explored the phototoxic effect in HER2+ cells of bioconjugates of trastuzumab and $\mathrm{H}_{2}$ Por. They introduced dibromopyridazinedione-strained alkyne moeities into the disulfide bond presented in the MAb with the subsequent use of a copper-free click reaction as a strategy to link water-soluble porphyrin azides. ${ }^{[88]}$ The bioconjugates showed the ability to kill HER2+ cells, without affecting HER2- cells and obtaining a low dark cytotoxicity.

Moreover, in the case of protein cages, the MS2 phage has been modified for acting as a nanocarrier of $\mathrm{H}_{2}$ Por obtaining excellent results of phototoxicity, with the advantage that this system can has specificity for certain cells or tissues. ${ }^{[89,90]}$

Related to carbohydrates, there are many examples in the literature about the synthesis of complexes of CD and Pors. An interesting example is the study carried out by Kano and co-workers, where they synthesized mimic complexes of haemoglobin/myoglobin to be used as an antidote for cyanide poisoning, composed by a $\beta$-CDdimer and $\mathrm{Fe}(\mathrm{III})$ Por $^{[91]}$ In other way, anionic tetrasulphonated $\mathrm{H}_{2}$ Por has been encapsulated in the inner cavity of octaarginine- $\beta-C D$ derivatives for intracellular delivery. [92] A very interesting approach is the use of Huisgen cycloaddition click reaction for the synthesis of this type of conjugates. Biohybrids of $\beta$-CD and $\mathrm{Zn}$ (II)Por have been synthesized, with the hypothesis of the authors of a possible use of this system as nanocontainer for including drugs in the inner cavity of $\mathrm{CD} .{ }^{[93]}$ As a last and interesting example, conjugates of $\beta$-CD-derivatives and $\mathrm{H}_{2}$ Por and $\mathrm{Zn}(\mathrm{II})$ Por have been employed in the study of Alzheimer's disease, with the modulation of the aggregation of peptides carried out for these conjugates. ${ }^{[94]}$

Otherwise, nanocrystalline cellulose has been used as a biological component in biohybrids with $\mathrm{H}_{2}$ Por and $\mathrm{Zn}$ (II) 
Por, using the covalent way as the chemical strategy, with the production of ${ }^{1} \mathrm{O}_{2} \cdot{ }^{[95]}$ Click chemistry has been also employed to link $\mathrm{Zn}$ (II)Por derivatives to iron oxide nanoparticles covered by dextran, for testing the PDT activity in human keratinocyte cells. ${ }^{[96]}$ Also, dextran has been bound to $\mathrm{Mn}$ (III)Por derivatives for improving the properties of these systems as MRI contrast agents. ${ }^{[97]}$

The combination of nucleic acids and Pors has been much less studied. Among them, the most representative example was reported by Czuchajowski and co-workers in 1997 when via solid phase synthesis they linked a $\mathrm{H}_{2}$ Por to oligonucleotides, $\mathrm{d}(\mathrm{TCTTCCCA})$ and $\mathrm{d}(\mathrm{T})_{12}{ }^{[98]}$ These conjugates were activated in the presence of the target 22-mer and 16-mer oligonucleotides, obtaining an excellent photomodification efficiency for a site-specific DNA ( $c a .5$ bases).

Regarding the formation of ternary biohybrids using Pors and liposomes, a benzoporphyrin derivative monoacid A (BPD), a FDA-approved drug, was associated into a stable preformed plain liposome (PPL) and the Cetuximab antibody for EGFR embedded on the outer membrane. ${ }^{[99]}$ BPDconjugate showed a high optical stability and more quantum yield than free-BPD. The Cetuximab presented a high selectivity towards cells that overexpressed EGFR whose inhibition increased the ovarian cancer cell death in Ovcar-5 and CAMA-1 cell lines. In this sense, a Por-liposomes composed by hexyloxyethy-pyropheophorbide (HPPH) demonstrated an effective and controlled release of cargo after NIR irradiation including when these systems were loaded with doxorubicin, an anticancer drug, whose efficiency in antitumor phototherapy could be enhanced. ${ }^{[100]}$ Furthermore, an interesting example was reported by Shao et al. where a Co(II)Por-liposome conjugate has been selectively linked to polyhistidine tag proteins and peptides. ${ }^{[101]}$ This biohybrid was also loaded with sulphorhodamine B in the inner cavity in order to visualise the cargo release in cancerous tissues of mice. Another exciting approach is the development of porhysomes that are spherical nanovesicles composed by self-assembled porphyrin bilayers. These porphysomes can be passively or actively loaded with different biomolecules such as antibodies or proteins, among others being enzymatically biodegradable and highly biocompatible. In a recent study, porphysomes composed by pyropheophorbide were accumulated in tumours of xenograft-bearing mice and were used as photothermal therapy agents. ${ }^{[102]}$ These results demonstrated an excellent potential of these systems for biophotonic imaging and therapy. As a last and interesting example, sulfonated polystyrene nanoparticles have been covered with Pcs and Pors, that were capable of produce ${ }^{1} \mathrm{O}_{2}$ and a photodonor that was capable of produce ${ }^{1} \mathrm{O}_{2}$ and NO under irradiation. ${ }^{[103]}$ However, the production of NO was dependent on the temperature, improving with the increase of this one. These systems were tested as agents in photodynamic inactivation, showing a high antibacterial action against $E$. coli.

\section{Other Porphyrinoids}

In other way, some examples of other PSs conjugated to peptides can be found in literature, mainly amino acids and antimicrobial peptides. Chlorins, such as chlorin $e_{6}{ }^{[104]}$ and chlorin $p_{6}{ }^{[105]}$ have been linked to aminoacids (lysine, aspartic acid and glutamic acid) in different positions. Chlorin $e_{6}$ derivative biohybrids were studied in vitro in human carcinoma Hep2 cells. Authors showed that all biohybrids were highly accumulated in cells and hypothesized that the biological activity may be determined by the molecular conformation of the biohybrid. In this sense, Yao and co-workers developed a water-soluble aspartylchlorin $p_{6}$ dimethylester biohybrid, highly phototoxic, against melanoma cells and scarce dark toxicity and, at the same time, they found an excellent antitumoral efficacy on mice bearing a B16-F10 tumour.

On the other hand, different types of PSs as BODIPYs have been used in PDI through the conjugation to antimicrobial peptides. In 2016, Vendrell et al. linked a BODIPY to fluorogenic tryptophan antimicrobial peptide without any kind of spacer among them. ${ }^{[106,107]}$ The resulting biohybrid had a dual behaviour, as imaging probe and as antifungal photodynamic agent. Excellent results were observed in ex vivo human tissues of $A$. fumigatus, fungi that causes fatal diseases in human such as invasive pulmonary aspergillosis (IPA). One year later, these same authors applied the previous methodology in order to obtain another fluorogenic, Trp-BODIPY cyclic peptide. This biohybrid was able to bind in apoptotic bodies from BL2 human lymphoma cells. ${ }^{[108]}$

Concerning the linkage of other PSs to HSA/BSA, there are diverse examples described in the literature. Nanospheres composed by biohybrids of HSA, poly-L-lysine and chlorin $e_{6}$ have been tested in HeLa, B16 and MCF-7 cell lines, evaluating the phototoxic effect, obtaining good results and showing no harmful effects in dark conditions. ${ }^{[109]}$ Regarding to other PSs, pheophorbide $a$ has been conjugated to BSA and polyethylene glycosylated folate, ${ }^{[10]}$ and a BODIPY to HSA and Mn(II) complexes and PEGfolic acid derivatives, ${ }^{[111]}$ giving interesting and promising results of generation of ROS.

As an important example in the design of biohybrids using MAbs as a targeting biomolecule, is the synthesis and the biological studies of a bioconjugate composed by a Ga(III) corrole and HerPBK10, that can target HER2. Apart from a phototoxic activity, this complex can act as imaging agent, being a promising agent in PDT and theranostics. $^{[112]}$

Unfortunately, the synthesis of conjugates between $\mathrm{CD}$ and other PSs has been not so explored. However, there are some examples in the literature that have to be mentioned. One or two units of $\beta-\mathrm{CD}$ have been linked to corrole, to evaluate the phototoxic effect in HeLa cells, with the generation of ${ }^{1} \mathrm{O}_{2}$ for both conjugates. ${ }^{[113]}$ A different interesting example is the linking of fluorinated chlorins to $\beta-\mathrm{CD}$, showing good results of phototoxicity and a highwater solubility. ${ }^{[114]}$

Regarding other carbohydrates, chitosan is a polysaccharide that comes from the deacetylation of chitin, which can be easily modified and shows interesting properties to be considered excellent nanomaterials for biomedical applications. ${ }^{[115]}$ Good results have been obtained in PDT experiments in tumour bearing mice, which have been carried out with the use of chitosan-chlorin conjugates. ${ }^{[16]}$ Other examples are the synthesis of photosensitizing nanoparticles composed by the linking of pheophorbide $a$ and glycol 
chitosan, ${ }^{[117]}$ and the use of biohybrids of iodinated chitosan and chlorin $e_{6}$ as PDT and imaging agents. ${ }^{[118]}$ Chlorin $e_{6}$ has been linked to dextran too, to test in HCT116 human colon cancer cells, the results of phototoxicity and cellular uptake, showing good results. ${ }^{[119]}$

Recently, in 2016, Hocek and co-workers developed a BODIPY fluorescent molecular rotor linked to a nucleoside to appreciate modifications in exogenous DNA microenvironment measuring the fluorescence lifetime in both in vitro and in cellulo. ${ }^{[120]}$ This sensor presented good photostability and versatility, and responded to DNA-binding proteins or lipids, or during the transfection of living cells.

In connection to oligonucleotides, two different chlorins were conjugated using linkers such as diamine or dihydrazide. ${ }^{[121]}$ These conjugates promoted selective damages to certain nucleic sequences although quantum yield of the photoprocess was moderate (Figure 6). Another different approach was developed by Zhang et al. where a BODIPY-based fluorescent sensor presented an exceptional affinity to parallel-stranded G-quadruplexes. ${ }^{[122]}$ This remarked selectivity promoted the disaggregation of PSs in aqueous media, and thus, the increase in the BODIPY fluorescence.

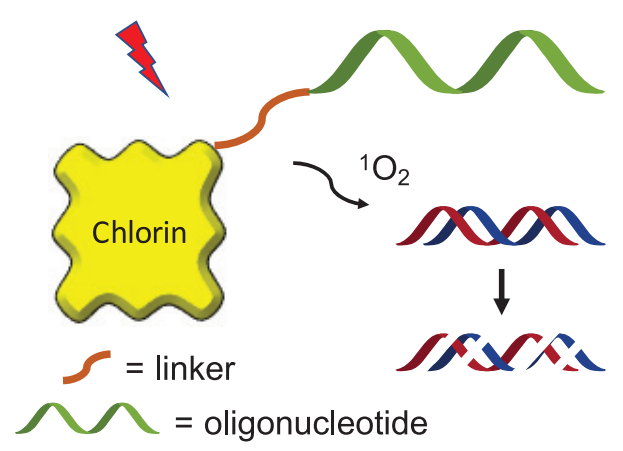

Figure 6. Bioconjugates of chlorins and oligonucleotides allow, under the irradiation of red light, the generation of ${ }^{1} \mathrm{O}_{2}$, and the photodamage of single-stranded or double-stranded nucleic acids.

As a final example, chlorins have been payloaded into polymeric micelles, for the treatment of cardiovascular diseases allowing the elimination of macrophages in atherosclerotic plaques. ${ }^{[123]}$

\section{Conclusion}

Photosensitizers based on phthalocyanines, porphyrins and related systems are interesting nanomaterials with multiple applications in different fields ranging from molecular photovoltaics ${ }^{[124-127]}$ to nanomedicine. ${ }^{[11,128-131]}$ The design of biohybrids materials by linking porphyrinoids and biomolecules allows the enhancement and the appearance of new valuable properties for the use of these complexes in a biological media. The literature is very extensive, and this review has covered only the most recent and interesting examples that comprises the conjugation of biomolecules through different methods for novel applications in the fields of for photodynamic therapy, photoinactivation of microorganisms and medical imaging, with the aim of stimulating the curiosity of the reader.

Acknowledgements. The work carried out was supported by the Spanish MINECO [CTQ2017-85393-P (TT) and PCIN-2017-042/ EuroNanoMed2017-191, TEMPEAT (TT)]. We thank also for a Juan de la Cierva fellowship (J.A.G-D).

\section{References}

1. Celli J.P., Spring B.Q., Rizvi I., Evans C.L., Samkoe K.S., Verma S., Pogue B.W., Hasan T. Chem. Rev. 2010, 110, 2795-2838.

2. Li X., Lee S., Yoon J. Chem. Soc. Rev. 2018, 47, 1174-1188.

3. Wainwright M., Maisch T., Nonell S., Plaetzer K., Almeida A., Tegos G.P., Hamblin M.R. Lancet Infect. 2017, 17, e49-e55.

4. Ethirajan M., Chen Y., Joshi P., Pandey R.K. Chem. Soc. Rev. 2011, 40, 340-362.

5. Moser J.G. Photodynamic Tumor Therapy: 2nd and 3rd Generation Photosensitizers. Amsterdam: Harwood Academic Publishers, 1998.

6. MacDonald I.J., Dougherty T.J. J. Porphyrins Phthalocyanines 2001, 5, 105-129.

7. Sewald N., Jakubke H.D. Application of Peptides and Proteins. Darmstadt: Wiley-VCH Verlag GmbH \& Co. KGaA, 2009.

8. Lu Y., Low P.S. Adv. Drug Delivery Rev. 2002, 54, 675-693.

9. Skupin-Mrugalska P., Piskorz J., Goslinski T., Mielcarek J., Konopka K., Düzgünes N. Drug Discovery Today 2013, 18 , 776-784.

10. Dwek R.A. Chem. Rev. 1996, 96, 683-720.

11. Almeida-Marrero V., van de Winckel E., Anaya-Plaza E., Torres T., de la Escosura A. Chem. Soc. Rev. 2018, 47, 7369-7400.

12. Sharman W.M., van Lier J.E., Allen C.M. Adv. Drug Delivery Rev. 2004, 56, 53-76.

13. Liu H.-Y., Huang J.-W., Tian X., Jiao X.-D., Luo G.-T., Ji L.-N. Chem. Commun. 1997, 16, 1575-1576.

14. Biron E., Voyer N. Chem. Commun. 2005, 37, 4652-4654.

15. Liu K., Zhang H., Xing R., Zou Q., Yan X. ACS Nano 2017, 11, $12840-12848$.

16. Yewale C., Baradia D., Vhora I., Patil S., Misra A. Biomaterials 2013, 34, 8690-8707.

17. Cornelio D.B., Roesler R., Schwartsmann G. Ann. Oncol. 2007, 1457-1466.

18. Wimley W.C., Hristova K. J. Membr. Biol. 2011, 239, 27-34.

19. Ongarora B.G., Fontenot K.R., Hu X., Sehgal I., Satyanarayana-Jois S.D., Vicente M.G.H. J. Med. Chem. 2012, 55, 3725-3738.

20. Yu L., Wang Q., Wong R.C.H., Zhao S., Ng D.K.P., Lo P-C. Dyes Pigm. 2019, 163, 197-203.

21. Mew D., Wat C.K., Towers G.H.N., Levy J.G. J. Immunol. 1983, 130, 1473-1477.

22. Kobayashi H., Choyke P.L. Nanoscale 2016, 8, 12504-12509.

23. Mitsunaga M., Ogawa M., Kosaka N., Rosenblum L.T., Choyke P.L., Kobayashi H. Nat. Med. 2011, 17, 1685-1691.

24. Mitsunaga M., Nakajima T., Sano K., Choyke P.L., Kobayashi H. Bioconjugate Chem. 2012, 23, 604-609.

25. Zhang J., Niu G., Lang L., Li F., Fan X., Yan X., Yao S., Yan W., Huo L., Chen L., Li Z., Zhu Z., Chen X. J. Nucl. Med. 2017, 58, 228-234.

26. Ranyuk E., Cauchon N., Klarskov K., Guérin B., van Lier J.E. J. Med. Chem. 2013, 56, 1520-1534. 
27. Fanali G., di Masi A., Trezza V., Marino M., Fasano M., Ascenzi P. Mol. Aspects Med. 2012, 33, 209-290.

28. Larroque C., Pelegrin A., van Lier J.E. Br. J. Cancer 1996, 74, 1886-1890.

29. Brasseur N., Langlois R., La Madeleine C., Ouellet R., van Lier J.E. Photochem. Photobiol. 1999, 69, 345-352.

30. Kollár J., Machacek M., Jancarova A., Kubat P., Kucera R., Miletin M., Novakova V., Zimcik P. Dyes Pigm. 2019, 162, 358-366.

31. Machacek M., Kollár J., Miletin M., Kucera R., Kubát P., Simunek T., Novakova V., Zimcik P. RSC Adv. 2016, 6, 10064-10077.

32. Li F., Zhao Y., Mao C., Kong Y., Ming X. Mol. Pharmaceutics 2017, 14, 2793-2804.

33. Uchida M., Klem M.T., Allen M., Suci P., Flenniken M., Gillitzer E., Varpness Z., Liepold L.O., Young M., Douglas T. Adv. Mater. 2007, 19, 1025-1042.

34. de la Escosura A., Nolte R.J.M., Cornelissen J.J.L.M. J. Mater. Chem. 2009, 19, 2274-2278.

35. Brasch M., De La Escosura A., Ma Y., Uetrecht C., Heck A.J.R., Torres T., Cornelissen J.J.L.M. J. Am. Chem. Soc. 2011, 133, 6878-6881.

36. Setaro F., Brasch M., Hahn U., Koay M.S.T., Cornelissen J.J.M.L., de la Escosura A., Torres T. Nano Lett. 2015, 15, $1245-1251$.

37. Mikkilä J., Anaya-Plaza E., Liljeström V., Ruíz-Castón J., Torres T., de la Escosura A., Kostiainen M.A. ACS Nano 2016, 10, 1565-1571.

38. Liu X., Qi C., Bing T., Cheng X., Shangguan D. Anal. Chem. 2009, 81, 3699-3704.

39. Nesterova I.V., Erdem S.S., Pakhomov S., Hammer R.P., Soper S.A. J. Am. Chem. Soc. 2009, 131, 2432-2433.

40. Nesterova I.V., Bennett C.A., Erdem S.S., Hammer R.P., Deininger P.L., Soper S.A. Analyst 2011, 136, 1103-1105.

41. Kopecky K., Novakova V., Miletin M., Kučera R., Zimcik P. Bioconjugate Chem. 2010, 21, 1872-1879.

42. Demuth J., Kucera R., Kopecky K., Havlínová Z., Libra A., Novakova V., Miletin M., Zimcik P. Chem. Eur. J. 2018, 24, 9658-9666.

43. Sessa G., Weissmann G. J. Biol. Chem. 1970, 245, 3295-3301.

44. García M.A., Alarcón E., Muñoz M., Scaiano J.C., Edwards A.M., Lissi E. Photochem. Photobiol. Sci. 2011, 10, 507-514.

45. Lv H.-J., Zhang X.-T., Wang S., Xing G.-W. Analyst 2017, 142, 603-607.

46. Pérez A.P., Casasco A., Schilrreff P., Tesoriero M.V.D., Duempelmann L., Altube M.J., Higa L., Morilla M.J., Petray P., Romero E.L. Int. J. Nanomed. 2014, 9, 3335-3345.

47. Gardner D.M., Taylor V.M., Cedeño D.L., Padhee S., Robledo S.M., Jones M.A., Lash T.D., Vélez I.D. Photochem. Photobiol. 2010, 86, 645-652.

48. Yang Y.-T., Chien H.-F., Chang P.-H., Chen Y.-C., Jay M., Tsai T., Chen C.-T. Lasers Surg. Med. 2013, 45, 175-185.

49. Séguier S., Souza S.L.S., Sverzut A.C.V., Simioni A.R., Primo F.L., Bodineau A., Correa V.M.A., Coulomb B., Tedesco A.T. J. Photochem. Photobiol. B 2010, 101, 348-354.

50. Mijan M.C., Longo J.P.F., Duarte de Melo L.N., Simioni A.R., Tedesco A.C., Azevedo R.B. J. Nanomed. Nanotechnol. 2014, 5, 218.

51. Broekgaarden M., de Kroon A.I.P.M., van Gulik T.M., Heger M. Curr. Med. Chem. 2014, 21, 377-391.

52. Castagnos P., Siqueira-Moura M.P., Goto P.L., Pérez E., Franceschi S., Rico-Lattes I., Tedesco A.C., Blanzat M. RSC Adv. 2014, 4, 39372-39377.

53. Feng L., Cheng L., Dong Z., Tao D., Barnhart T.E., Cai W., Chen M., Liu Z. ACS Nano 2017, 11, 927-937.

54. Feng L., Tao D., Dong Z., Chen Q., Chao Y., Liu Z., Chen M. Biomaterials 2017, 127, 13-24.
55. Tachikawa S., El-Zaria M.E., Inomata R., Sato S., Nakamura H. Bioorg. Med. Chem. 2014, 22, 4745-4751.

56. Zhou F., Feng B., Wang T.T., Wang D.G., Meng Q.S., Zeng J.F., Zhang Z.W., Wang S.L., Yu H.J., Li Y.P. Adv. Funct. Mater. 2017, 27, 1606530.

57. Morgan J., Gray A.G., Huehns E.R. Br. J. Cancer 1989, 59, 366-370.

58. Morgan J., MacRobert A., Gray A.G., Huehns E.R. Br. J. Cancer 1992, 65, 58-64.

59. Broekgaarden M., van Vught R., Oliveira S., Roovers R.C., van Bergen EnHenegouwen P.M.P., Pieters R.J., van Gulik T.M., Breukink E., Heger M. Nanoscale 2016, 8, 6490-6494.

60. Gijsens A., Derycke A., Missiaen L., De Vos D., Huwyler J., Eberle A., de Witte P. Int. J. Cancer 2002, 101, 78-85.

61. Derycke A.S.L., Kamuhabwa A., Gijsens A., Roskams T., De Vos D., Kasran A., Huwyler J., Missiaen L., de Witte P.A.M. J. Natl. Cancer Inst. 2004, 96, 1620-1630.

62. Ngweniform P., Abbineni G., Cao B., Mao C. Small 2009, 5 , 1963-1969.

63. Hota R., Baek K., Yun G., Kim Y., Jung H., Park K.M., Yoon E., Joo T., Kang J., Park C.G., Bae S.M., Ahn W.S., Kim K. Chem. Sci. 2013, 4, 339-344.

64. Ikonen E. Nat. Rev. Mol. Cell Biol. 2008, 9, 125-138.

65. Segalla A., Milanesi C., Jori G., Capraro H.G., Isele U., Schieweck K. Br. J. Cancer 1994, 69, 817-825.

66. Samavat H., Kurzer M.S. Cancer Lett. 2015, 356, 231-243.

67. Khan E.H., Ali H., Tian H., Rousseau J., Tessier G., Shafiullah M., van Lier J.E. Bioorg. Med. Chem. Lett. 2003, 13, $1287-1290$.

68. Maillard P., Gaspard S., Guerquin-Kernand J.L., Momenteau M. J. Am. Chem. Soc. 1989, 111, 9125-9127.

69. Fülling G., Schröder D., Franck B. Angew. Chem. Int. Ed. Engl. 1989, 28, 1519-1521.

70. Crini G. Chem. Rev. 2014, 114, 10940-10975.

71. Ribeiro A.O., Tomé J.P.C., Neves M.G.P.M.S., Tomé A.C., Cavaleiro J.A.S., Serra O.A., Torres T. Tetrahedron Lett. 2006, 47, 6129-6132.

72. Lourenço L.M.O., Pereira P.M.R., Maciel E., Válega M., Domingues F.M.J., Domingues M.R.M., Neves M.G.P.M.S., Cavaleiro J.A.S., Fernandes R., Tomé J.P.C. Chem. Commun. 2014, 50, 8363-8366.

73. Moon R.J., Martini A., Nairn J., Simonsen J., Youngblood J. Chem. Soc. Rev. 2011, 40, 3941-3994.

74. Anaya-Plaza E., van de Winckel E., Mikkilä J., Malho J.M., Ikkala O., Gulías O., Bresolí-Obach R., Agut M., Nonell S., Torres T., Kostiainen M.A., de la Escosura A. Chem. Eur. J. 2017, 23, 4320-4326.

75. Sun G., Mao J.J. Nanomedicine 2012, 7, 1771-1784.

76. Fraix A., Gref R., Sortino S. J. Mater. Chem. B 2014, 2, 3443-3449.

77. Ylä-Herttuala S., Bolstad Christensen J.B., Moghimi S.M., Torres Cebada T., Trohopoulos P.N., Makinen P., Ficker M., Wu L., Medel-Gonzalez M. Nano-Systems for Therapy and/ or Diagnosis and/or Therapy Monitoring and/or Theragnostic of Disease. PCT/EP 16168476.6; 05/05/2016.

78. Ylä-Herttuala S., Mäkinen P., van Nostrum C.F., Wennink J.W.H., Torres Cebada T., de la Escosura Navazo A., Setaro F., van de Winckel E., Trohopoulos P.N. Polymeric Micellephthalocyanine Nano-Systems for Photodynamic Therapy and/or Fluorescence-Based Imaging. PCT/EP 16177001.1; 29/06/2016.

79. Dozzo P., Koo M.-S., Berger S., Forte T.M., Kahl S.B. J. Med. Chem. 2005, 48, 357-359.

80. Sibrian-Vázquez M., Jensen T.J., Vicente M.G.H. J. Med. Chem. 2008, 51, 2915-2923.

81. Sehgal I., Sibrian-Vázquez M., Vicente M.G.H. J. Med. Chem. 2008, 51, 6014-6020. 
82. Sibrian-Vázquez M., Jensen T.J., Hammer R.P., Vicente M.G.H. J. Med. Chem. 2006, 49, 1364-1372.

83. Doselli R., Tampieri C., Ruiz-González R., De Munari S., Ragás X., Sánchez-García D., Agut M., Nonell S., Reddi E., Gobbo M. J. Med. Chem. 2013, 56, 1052-1063.

84. Gueddari N., Favre G., Hachem H., Marek E., Le Gaillard F., Soula G. Biochimie 1993, 75, 811-819.

85. Bricarello D.A., Smilowitz J.T., Zivkovic A.M., German J.B., Parikh A.N. ACS Nano 2011, 5, 42-57.

86. Shaw J.M. Lipoproteins as Carriers of Pharmacological Agents. New York: Dekker, 1991. 408 p.

87. Tang J., Chen J.-J., Jing J., Chen J.-Z., Lv H., Yu Y., Xu P., Zhang J.-L. Chem. Sci. 2014, 5, 558-566.

88. Maruani A., Savoie H., Bryden F., Caddick S., Boyle R., Chudasama V. Chem. Commun. 2015, 51, 15304-15307.

89. Cohen B.A., Bergkvist M. J. Photochem. Photobiol. B 2013, $121,67-74$.

90. Stephanopoulos N., Tong G.J., Hsiao S.C., Francis M.B. ACS Nano 2010, 4, 6014-6020.

91. Watanabe K., Kitagishi H., Kano K. Angew. Chem. Int. Ed. 2013, 52, 6894-6897.

92. Kitagishi H., Chai F., Negi S., Sugiura Y., Kano K. Chem. Commun. 2015, 51, 2421-2424.

93. Zhao J., Zhang H.-Y., Sun H.-L., Liu Y. Chem. Eur. J. 2015, $21,4457-4464$

94. Oliveri V., Zimbone S., Giuffrida M.L., Bellia F., Tomasello M.F., Vecchio G. Chem. Eur. J. 2018, 24, 6349-6353.

95. Chauhan P., Hadad C., Sartorelli A., Zarattini M., HerrerosLópez A., Mba M., Maggini M., Prato M., Carofiglio T. Chem. Commun. 2013, 49, 8525-8527.

96. Mbakidi J.P., Brégier F., Ouk T.S., Granet R., Alves S., Rivière E., Chevreux S., Lemercier G., Sol V. ChemPlusChem 2015, 80, 1416-1426.

97. Zhang Z., He R., Yan K., Guo Q.-N., Lu Y.-G., Wang X.-X., Lei H., Li Z.-Y. Bioorg. Med. Chem. Lett. 2009, 19, 66756678.

98. Li H., Fedorova O.S., Trumble W.R., Fletcher T.R., Czuchajowski L. Bioconjugate Chem. 1997, 8, 49-56.

99. Mir Y., Elrington S.A., Hasan T. Nanomedicine 2013, 9, 1114-1122.

100. Carter K.A., Shao S., Hoopes M.I., Luo D., Ahsan B., Grigoryants V.M., Song W., Huang H., Zhang G., Pandey R.K., Geng J., Pfeifer B.A., Scholes C.P., Ortega J., Karttunen M., Lovell J.F. Nat. Commun. 2014, 5, 3546.

101. Shao S., Geng J., Yi H.A., Gogia S., Neelamegham S., Jacobs A., Lovell J.F. Nat. Chem. 2015, 7, 438-446.

102. Lovell J.F., Jin C.S., Huynh E., Jin H., Kim C., Rubinstein J.L., Chan W.C.W., Cao W., Wang L.V., Zheng G. Nat. Mat. 2011, 10, 324-332.

103. Dolansky J., Henke P., Malá Z., Zárská L., Kubát P., Mosinger J. Nanoscale 2018, 10, 2639-2648.

104. Jinadasa R.G.W., Hu X., Vicente M.G.H., Smith K.M. J. Med. Chem. 2011, 54, 7464-7476.

105. Meng Z., Yu B., Han G., Liu M., Shan B., Dong G., Miao Z., Jia N., Tan Z., Li B., Zhang W., Zhu H., Sheng C., Yao J. J. Med. Chem. 2016, 59, 4999-5010.

106. Mendive-Tapia L., Subirós-Funosas R., Zhao C., Albericio F., Read N.D., Lavilla R., Vendrell M. Nat. Protoc. 2017, 12, $1588-1619$.

107. Mendive-Tapia L., Zhao C., Akram A.R., Preciado S., Albericio F., Lee M., Serrels A., Kielland N., Read N.D., Lavilla R., Vendrell M. Nat. Commun. 2016, 7, 10940.
108. Subirós-Funosas R., Mendive-Tapia L., Sot J., Pound J.D., Barth N., Varela Y., Goñi F.M., Paterson M., Gregory C.D., Albericio F., Dransfield I., Lavilla R., Vendrell M. Chem. Commun. 2017, 53, 945-948.

109. Zhang N., Zhao F., Zou Q., Li Y., Ma G., Yan X. Small 2016, 12, 5936-5943.

110. Battogtokh G., Ko Y.T. J. Mater. Chem. B 2015, 3, 9349-9359.

111. Lu W.-L., Lan Y.-Q., Xiao K.-J., Xu Q.-M., Qu L.-L., Chen Q.-Y., Huang T., Gao J., Zhao Y. J. Mater. Chem. B 2017, 5, $1275-1283$.

112. Agadjanian H., Ma J., Rentsendorj A., Valluripalli V., Hwang J.Y., Mahammed A., Farkas D.L., Gray H.B., Gross Z., Medina-Kauwe L.K. Proc. Natl. Acad. Sci. USA 2009, 106, $6105-6110$.

113. Barata J.F.B., Zamarrón A., Neves M.G.P.M.S., Faustino M.A.F., Tomé A.C., Cavaleiro J.A.S., Róder B., Juarranz A., Sanz-Rodríguez F. Eur. J. Med. Chem. 2015, 92, 135-144.

114. Silva J.N., Silva A.M.G., Tomé J.P., Ribeiro A.O., Domingues M.R.M., Cavaleiro J.A.S., Silva A.M.S., Neves M.G.P.M.S., Tomé A.C., Serra O.A., Bosca F., Filipe P., Santus R., Morlière P. Photochem. Photobiol. Sci. 2008, 7, 834-843.

115. Shukla S.K., Mishra A.K., Arotiba O.A., Mamba B.B. Int. J. Biol. Macromol. 2013, 59, 46-58.

116. Gaware V.S., Hakerud M., Juzeniene A., Hogset A., Berg K., Másson M. Biomacromolecules 2017, 18, 1108-1126.

117. Oh I.-H., Min H.S., Li L., Tran T.H., Lee Y.-K., Kwon I.C., Choi K., Kimand K., Huh K.M. Biomaterials 2013, 34, 6454-6463.

118. Lim C.-K., Shin J., Kwon I.C., Jeong S.Y., Kim S. Bioconjugate Chem. 2012, 23, 1022-1028.

119. Chu C.W., Ryu J.H., Jeong Y.-I., Kwak T.W., Lee H.L., Kim H.Y., Son G.M., Kim H.W., Kang D.H. J. Nanomater. 2016, 2016, 4075803.

120. Dziuba D., Jurkiewicz P., Cebecauer M., Hof M., Hocek M. Angew. Chem. 2016, 128, 182-186.

121. Boutorine A.S., Brault D., Takasugi M., Delgado O., Hélène C. J. Am. Chem. Soc. 1996, 118, 9469-9476.

122. Zhang L., Er J.C., Ghosh K.K., Chung W.J., Yoo J., Xu W., Zhao W., Phan A.T., Chang Y.T. Sci. Rep. 2014, 4, 3776.

123. Wennink J.W.H., Liu Y., Mäkinen P.I., Setaro F., de la Escosura A., Bourajjaj M., Lappalainen J.P., Holappa L.P., van den Dikkenberg J.B., al Fartousi M., Trohopoulos P.N., Ylä-Herttuala S., Torres T., Hennink W.E., van Nostrum C.F. Eur. J. Pharm. Sci. 2017, 107, 112-125.

124. Ragoussi M.-E., Torres T. Chem. Commun. 2015, 51, 39573972.

125. Urbani M., Ragoussi M.-E., Nazeeruddin M.K., Torres T. Coord. Chem. Rev. 2019, 381, 1-64.

126. Hardin B.E., Yum J.-H., Hoke E.T., Jun Y.C., Péchy P., Torres T., Brongersma M.L., Nazeeruddin M.K., Grätzel M., McGehee M.D. Nano Lett. 2010, 10, 3077-3083.

127. Morandeira A., López-Duarte I., O’Regan B., Martínez-Díaz M.V., Forneli A., Palomares E., Torres T., Durrant J.R. J. Mater. Chem. 2009, 19, 5016-5026.

128. González-Delgado J.A., Kennedy P.J., Ferreira M., Tomé J.P.C., Sarmento B. J. Med. Chem. 2016, 59, 4428-4442.

129. Abrahamse H., Hamblin M.R. Biochem. J. 2016, 473, 347-364.

130. Heukers R., van Bergen en Henegouwen P.M., Oliveira S. Nanomedicine 2014, 10, 1441-1451.

131. Kwiatkowski S., Knap B., Przystupski D., Saczko J., Kędzierska E., Knap-Czop K., Kotlińska J., Michel O., Kotowski K., Kulbacka J. Biomed. Pharmacother. 2018, 106, 1098-1107. 